\title{
Lung cancer mortality among residents living near the El Paso smelter
}

\author{
W N ROM, GLORIA VARLEY, J L LYON, AND SARA SHOPKOW \\ From the Rocky Mountain Centre for Occupational and Environmental Health and the Departments of \\ Internal Medicine and Family and Community Medicine, University of Utah, Salt Lake City, Utah 84112, \\ USA
}

ABSTRACT Occupational exposure to arsenic has been associated with cancer of the lung, but epidemiological studies of cancer of the lung and environmental exposure to arsenic have produced conflicting results. Case-control studies about point sources of pollution have been useful in identifying environmental hazards. This technique was used to evaluate the risk for lung cancer near a smelter in El Paso, Texas, that uses an arsenic-containing ore and has been in continuous operation since 1887 . A comparison of 575 cases of lung cancer with 1490 breast and prostate controls collected from 1944 to 1973 found no significant associations with distance using 2-km concentric circles out to $20 \mathrm{~km}$ from the smelter.

Epidemiological research over the past few decades has shown an association between lung cancer and occupational exposure to arsenic. ${ }^{1-6}$ Several studies have extended these observations to evaluate the risk of lung cancer in the community from environmental exposure to arsenic but have not found consistent results. ${ }^{7-10}$ Blot and Fraumeni ${ }^{7}$ found an association of lung cancer in counties in which non-ferrous smelters (primarily copper) were located. Matanoski et $\mathrm{al}^{\mathbf{8}}$ found increased mortality from lung cancer in a population near a pesticide factory manufacturing various arsenical pesticides in Baltimore after excluding those who were occupationally exposed. A similar study in Sweden about a non-ferrous smelter also found excess mortality from lung cancer, but the association disappeared when those occupationally exposed were excluded. ${ }^{9}$ Greaves et al $^{10}$ found no excessive lung cancer among people living near 10 different non-ferrous smelters in five western states compared with control cancers. Currently, there is no explanation for this disagreement, but one hypothesis is that the deposition pattern of arsenic-associated particles is very close to the smelter stack or point source of pollution; it is possible that exposure to arsenic has not been widespread. ${ }^{11}$

Since the previous studies were limited by small numbers of study subjects and short periods of

Supported by a contract from the Smelter Environmental Research Association.

Received 14 October 1981

Accepted 27 November 1981 observation of mortality, a study of the non-ferrous smelter at El Paso, Texas, was initiated. This smelter has been in continuous operation since 1887 and cancer mortality data were available from 1944 to 1973. Furthermore, a raised lung cancer SMR for women in El Paso County had been noted.' The hypothesis to be tested was that there was an excess of cases of lung cancer near a smelter compared with control cancers unrelated to arsenic, and that there would be a gradient with distance.

\section{Methods}

The methods used were identical to those used by Greaves et al ${ }^{10}$ and developed by Lyon $e t$ al, ${ }^{12}$ where addresses of patients with lung cancer and breast and prostate controls were plotted on United States Geological Survey maps after being located on local street maps. Only addresses within a $20-\mathrm{km}$ radius of the smelter stack were plotted, because beyond this distance smelter emission concentrations are low. ${ }^{13}$ The data were analysed by comparing the frequency of lung cancers and control cancers in concentric circles from the smelter stack. Distance from the smelter stack was used as a proxy for exposure to arsenic-containing smelter effluent.

The cancer data were obtained from the Texas Cancer Co-ordinating Council which began collecting cancer data in El Paso County in 1944. Data from 1944 to 1949 were collected from death certificates and hospital charts; from 1950 to 1973 incidence data collected at the time of diagnosis 
were used. In addition to the address, information was also obtained on race, sex, age, site of cancer, and year of diagnosis.

The selection of controls was based on two premises: firstly, information on controls had been reported and stored in the same manner as that for cases to prevent selection bias, and, secondly, the control cancers were not linked to arsenic as a causative agent.

The smelter is in the southwest section of El Paso bordered by the Rio Grande River to the south, the Franklin Mountains to the east (between the smelter and El Paso city), and foothills to the north. The El Paso smelter processes primarily lead and copper ores, but a zinc plant was added in 1948. Reconstruction of the smelter including environmental controls was undertaken in 1977. Smeltertown, which was a community adjacent to the smelter, was closed in the mid-1970s because of excessive lead absorption among children living 1-2 $\mathrm{km}$ from the smelter. ${ }^{14}$ Only one patient with lung cancer had a Smeltertown address for the period of the study.

The data were tested by the Mantel-Haenszel Chi-square procedure for an association between distance from the smelter and type of cancer. ${ }^{15}$ The relative risk (odds ratio) was computed and confidence limits were determined. The distance rings $0-1.99 \mathrm{~km}$ and $2-20 \mathrm{~km}$ were retested as the closer ring was increased in $2-\mathrm{km}$ increments. The stepwise increase in the radius of the ring closer to the smelter increased the possibility of detecting a difference between case and control cancers. This technique computes the expected frequency of cases based on the control distribution in concentric circles from a point source. ${ }^{12}$ Each distance ring was controlled for age by three strata (under 50, 50 to 70, over 70), sex, and race.

\section{Results}

A total of 2465 cases of cancer from 1944 to 1973 were collected: addresses for 2065 were actually plotted. The 400 not plotted were excluded for the following reasons: (1) 60 addresses were not within the $20-\mathrm{km}$ radius limit; (2) 250 had no address information; (3) 68 had incomplete addresses or could not be located on street maps; and (4) 22 had box numbers only. Of the 400 cases not plotted, 170 were lung cancer (42\%), 151 breast cancer (38\%), and 79 prostate cancer $(20 \%)$.

There were 575 cases of lung cancer ( 413 men, $72.2 \%), 376$ male controls (prostate), and 1114 female controls. Table 1 lists the study cases by sex and race.

Table 2 compares the number and percentage of cases and controls by distance ring. There were no significant differences between cases and controls for any of the concentric ring comparisons. The distribution of lung and control cases at different distances from the smelter was roughly the same. Table 3 compares the men with lung cancer with the prostate cancer controls with similar negative results. The distribution was also the same when comparing all cases of lung cancer or women with lung cancer only with breast cancer controls.

There was no association between lung cancer and distance from the smelter when controlling for race, or when analysing non-white or Spanish surnames singly or in combination. There were also no associations based on the three age groups analysed, nor for sex.

\section{Conclusions}

No association was found between lung cancer and distance from the El Paso smelter compared with control cancers for the period 1944-73 for 575 cases and 1490 controls. The same methods were used as in the previous study of 10 smelters in five western states. ${ }^{10}$ Problems inherent in using these methods include: (1) addresses used for plotting were addresses at the time of diagnosis, thus previous residence over the 20-30 year latency period for environmental carcinogenesis was not known for either cases or controls; (2) migration rates into and out of the 20 $\mathrm{km}$ radius were not known; and (3) measures of environmental exposure were not obtained over the years of the study.

Patterns of migration and population were similar for cases and controls, as in our previous study. ${ }^{10}$ Polissar ${ }^{16}$ has presented data that migration patterns could affect cases and controls similarly when comparing disease rates in geographical studies in the United States. Ambient air levels of arsenic were recorded by the El Paso City-County Health Department from 1972 to 1979 at a site near the smelter. ${ }^{17}$ The number of quarters having levels (arithmetical quarterly mean) in the following ranges were: $0-0.5 \mu \mathrm{g} / \mathrm{m}^{3}=15 ; 0.5-1 \mu \mathrm{g} / \mathrm{m}^{3}=9$; $1-1.5 \mu \mathrm{g} / \mathrm{m}^{3}=4$; and $>1.5 \mu \mathrm{g} / \mathrm{m}^{3}=2 .{ }^{17}$ Landrigan and Baker ${ }^{13}$ have shown that atmospheric concentrations of arsenic decrease logarithmically with distance at several smelters including El Paso. They also found that arsenic declined from a high of 2.5 $\mu \mathrm{g} / \mathrm{m}^{3}$ at the smelter property line to background levels less than $0.05 \mu \mathrm{g} / \mathrm{m}^{3}$ at a distance of $3-5 \mathrm{~km}$ from the smelter (six-month mean in 1972).${ }^{13}$ Blood lead concentrations were also shown to decline in the local denizens with distance from the smelter. Landrigan and Baker also found raised concentration of urine arsenic in children aged 1-5 in 10 of 11 communities with copper smelters compared with 
Table 1 Cancer and control cases by race and sex

\begin{tabular}{|c|c|c|c|c|c|c|}
\hline \multirow[b]{2}{*}{ Race and sex } & \multicolumn{2}{|l|}{ Case } & \multicolumn{2}{|c|}{ Control } & \multicolumn{2}{|l|}{ Total } \\
\hline & No & $\%$ & No & $\%$ & No & $\%$ \\
\hline $\begin{array}{l}\text { White } \\
\text { Men } \\
\text { Women } \\
\text { Non-white } \\
\text { Men } \\
\text { Women } \\
\text { Spanish surname } \\
\text { Men } \\
\text { Women } \\
\text { Missing information } \\
\text { Totals }\end{array}$ & $\begin{array}{r}362 \\
286 \\
76 \\
10 \\
7 \\
3 \\
200 \\
120 \\
80 \\
3 \\
575\end{array}$ & $\begin{array}{r}63 \cdot 0 \\
49.7 \\
13 \cdot 2 \\
1.7 \\
1 \cdot 2 \\
0 \cdot 5 \\
34 \cdot 8 \\
20 \cdot 9 \\
13.9 \\
0.5\end{array}$ & $\begin{array}{r}1015 \\
245 \\
770 \\
19 \\
7 \\
12 \\
456 \\
135 \\
321 \\
1490\end{array}$ & $\begin{array}{r}68 \cdot 1 \\
16 \cdot 4 \\
51 \cdot 7 \\
1 \cdot 3 \\
0.5 \\
0 \cdot 8 \\
30 \cdot 7 \\
9 \cdot 1 \\
21 \cdot 5 \\
\end{array}$ & $\begin{array}{r}1377 \\
531 \\
846 \\
29 \\
14 \\
15 \\
656 \\
255 \\
401 \\
3 \\
2065\end{array}$ & $\begin{array}{r}66 \cdot 7 \\
25 \cdot 7 \\
41 \cdot 0 \\
1.4 \\
0.7 \\
0.7 \\
31 \cdot 8 \\
12.3 \\
19.4 \\
0.1\end{array}$ \\
\hline
\end{tabular}

Table 2 Cases of lung cancer compared with all controls by distance

\begin{tabular}{|c|c|c|c|c|c|c|}
\hline \multirow[t]{2}{*}{ Distance rings $(\mathrm{km})$} & \multicolumn{2}{|c|}{ Cases of cancer } & \multicolumn{2}{|c|}{ Combined controls } & \multirow[t]{2}{*}{ Odds ratio } & \multirow[t]{2}{*}{$95 \%$ confidence intervals } \\
\hline & No & $\%$ & No & $\%$ & & \\
\hline $\begin{array}{r}0-2 \\
3-4 \\
5-6 \\
7-8 \\
9-10 \\
11-12 \\
13-14 \\
15-16 \\
17-18 \\
19-20\end{array}$ & $\begin{array}{r}4 \\
85 \\
140 \\
111 \\
63 \\
31 \\
25 \\
27 \\
60 \\
29\end{array}$ & $\begin{array}{r}0.7 \\
14 \cdot 8 \\
24.3 \\
19.3 \\
11 \cdot 0 \\
5.4 \\
4.3 \\
4.7 \\
10 \cdot 4 \\
5.0\end{array}$ & $\begin{array}{r}10 \\
264 \\
292 \\
357 \\
169 \\
81 \\
80 \\
71 \\
100 \\
66\end{array}$ & $\begin{array}{r}0.7 \\
17.7 \\
19.6 \\
24.0 \\
11.3 \\
5.4 \\
5.4 \\
4.8 \\
6.7 \\
4.4\end{array}$ & $\begin{array}{l}1.04 \\
0.81 \\
1.08 \\
0.89 \\
0.85 \\
0.83 \\
0.75 \\
0.68 \\
0.87\end{array}$ & $\begin{array}{l}0.27-4.00 \\
0.63-1.10 \\
0.88-1.30 \\
0.73-1.10 \\
0.68-1.10 \\
0.65-1.10 \\
0.57-0.96 \\
0.49-0.91 \\
0.53-1.40\end{array}$ \\
\hline Totals & 575 & $27 \cdot 8$ & 1490 & $72 \cdot 2$ & & \\
\hline
\end{tabular}

Table 3 Cases of lung cancer compared with prostate cancer by distance

\begin{tabular}{|c|c|c|c|c|c|c|}
\hline \multirow[t]{2}{*}{ Distance rings $(\mathrm{km})$} & \multicolumn{2}{|c|}{ Male lung } & \multicolumn{2}{|c|}{ Cases of prostate cancer } & \multirow[t]{2}{*}{ Odds ratio } & \multirow[t]{2}{*}{$95 \%$ confidence intervals } \\
\hline & No & $\%$ & No & $\%$ & & \\
\hline $\begin{array}{r}0-2 \\
3-4 \\
5-6 \\
7-8 \\
9-10 \\
11-12 \\
13-14 \\
15-16 \\
17-18 \\
19-20\end{array}$ & $\begin{array}{l}4 \\
68 \\
96 \\
84 \\
44 \\
18 \\
19 \\
19 \\
42 \\
19\end{array}$ & $\begin{array}{r}1.0 \\
16.5 \\
23 \cdot 2 \\
20 \cdot 3 \\
10 \cdot 7 \\
4.4 \\
4.6 \\
4.6 \\
10 \cdot 2 \\
4.6\end{array}$ & $\begin{array}{r}2 \\
67 \\
76 \\
100 \\
45 \\
25 \\
15 \\
11 \\
19 \\
16\end{array}$ & $\begin{array}{r}0 \cdot 5 \\
17 \cdot 8 \\
20 \cdot 2 \\
26 \cdot 6 \\
12 \cdot 0 \\
6 \cdot 6 \\
4 \cdot 0 \\
2 \cdot 9 \\
5 \cdot 1 \\
4 \cdot 3\end{array}$ & $\begin{array}{l}1.83 \\
0.94 \\
1.09 \\
0.84 \\
0.75 \\
0.61 \\
0.58 \\
0.59 \\
0.92\end{array}$ & $\begin{array}{l}0.26-12.40 \\
0.64-1.40 \\
0.81-1.50 \\
0.62-1.10 \\
0.54-1.00 \\
0.43-0.89 \\
0.39-0.88 \\
0.38-0.94 \\
0.44-1.90\end{array}$ \\
\hline Totals & 413 & & 376 & & & \\
\hline
\end{tabular}

control communities in a nationwide study. The annual windrose pattern at the smelter predominates from north-south and west-east, which could carry pollutants to more populated areas. ${ }^{13}$

Arsenic may not be dispersed very far from a smelter-emitting source. Ball ${ }^{\prime \prime}$ found that at a smelicr of similar age to that at El Paso soil samples analysed for arsenic were high within $2 \mathrm{~km}$ but dropped dramatically to background levels 5 to 10 km away.
The confounding factors of occupation and smoking were not controlled because of lack of access to this information. Controlling for these, however, would probably decrease the strength of an association between place of residence and lung cancer.

In summary, these results, along with the previous smelter study, do not support the hypothesis that community arsenical air pollution in counties with non-ferrous smelters is responsible for high lung cancer SMRs. 
We thank Ms Eleanor MacDonald, emeritus epidemiologist and statistician at M D Anderson Hospital in Houston, who was instrumental in obtaining the data. We also thank Ms Miki Coleman and Grace Chiu for statistical help and Ms Mary Bishop for typing the manuscript.

\section{References}

' Hill AB, Faning EL. Studies in the incidence of cancer in a factory handling inorganic compounds of arsenic. I Mortality experience in the factory. $\mathrm{Br} J$ Ind Med 1948;5:1-6.

${ }^{2}$ Kuratsune M, Tokudome S. Shiradkusa T, et al. Occupational lung cancer among copper smelters. Int $J$ Cancer 1974;13:552-8.

${ }^{3}$ Lee AM, Fraumeni JF. Arsenic and respiratory cancer in man: an occupational study. $J$ Natl Cancer Inst 1969;42:1045-52.

4 Milham S, Strong T. Human arsenic exposure in relation to a copper smelter. Environ Res 1974;7:176-82.

s Pinto SS, Enterline PE, Henderson V, Varner MO. Mortality experience in relation to a measured arsenic trioxide exposure. Environ Health Perspect 1977;19:127-30.

- Rencher AC, Carter MW, McKee AW. A retrospective epidemiological study of mortality at a large western copper smelter. JOM 1977;19:754-8.

${ }^{7}$ Blot WJ, Fraumeni JF. Arsenical air pollution and lung cancer. Lancet 1975;ii:142-4.
- Matanoski GM, Landau E, Tonasicia J, et al. Cancer mortality in an industrial area of Baltimore. Environ Res 1981;25:8-26.

- Pershagen G, Elinder CG, Bolander AM. Mortality in a region surrounding an arsenic emitting plant. Environ Health Perspect 1977;19:133-7.

${ }^{10}$ Greaves W, Rom WN, Lyon JL, Varley G, Wright D. Relationship between lung cancer and distance of residence from non-ferrous smelter stack effluent. American Journal of Industrial Medicine 1981;2:15-23.

"Ball AL. Arsenic distribution in soils surrounding the Garfield, Utah, copper smelter. Salt Lake City: University of Utah, 1980. (Master's thesis.)

${ }^{12}$ Lyon JL, Klauber MR, Graff W, Chiu G. Cancer clustering around point sources of pollution: assessment by a casecontrol methodology. Environ Res 1981;25:29-34.

13 Landrigan PJ, Baker EL. Exposure of children to heavy metals from smelters: epidemiology and toxic consequences. Environ Res 1981;25:204-24.

14 Morse DL, Landrigan PJ, Rosenblum BF, Honsworth J. El Paso revisited. Epidemiologic follow-up of an environmental lead problem. JAMA 1979;242:739-41.

${ }^{15}$ Mantel N. Chi-square tests with one degree of freedom: extensions of Mantel-Haenszel procedure. American Statistical Association Journal 1963;58:690-700.

${ }^{10}$ Polissar L. The effects of migration on comparison of disease rates in geographic studies in the United States. Am J Epidemiol 1980;111:175-82.

${ }^{17}$ Hubert JS, Candelaria RM, Rosenblum B, Munoz R, Applegate HG. A survey of ambient air levels of arsenic and cadmium in El Paso, Texas, from 1972 to 1979. Journal of the American Air Pollution Control Association 1981;31:261-2. 